\title{
Cultural Competence in Teaching Arabic as a Foreign Language
}

\author{
Magdalena Lewicka*, Anna Waszau \\ Department of Arabic Culture and Language, Nicolas Copernicus University, Poland
}

Copyright $(2016$ by authors, all rights reserved. Authors agree that this article remains permanently open access under the terms of the Creative Commons Attribution License 4.0 International License

\begin{abstract}
The paper is dedicated to the characteristics of the proposal regarding the cultural and regional knowledge curriculum of the Arabic language area whose realization should be correlated with practical teaching of the Arabic Language, both in universities and in language courses. The prototype and the basis for the development of this curriculum proposal is the cultural program for teaching Polish as a foreign language written by Władysław Miodunko, including the official guidelines regarding this matter and following other, similar concepts regarding the presentation of the cultural and regional knowledge material in the didactics of the foreign language teaching. The cultural program prepared by the authors includes many elements which compose the Arabic culture, especially in the context of its distinctness on the basis of the customs of the European societies and, what follows, the traditional, everlasting components, but also the ones which are a kind of novelty connected with the globalization and westernization processes coming around in the Arab world as a result of its contact with the West which causes gradual changes in the mentality and perception of the world by Arabs themselves. This elaboration also includes the method of teaching cultural and regional matters which - as Katarzyna Stankiewicz indicates - "can be taught in many ways - as a collection of facts to be remembered, information allowing the learner to find himself in the foreign reality or, finally, as an encouragement to reflection on one's own culture".
\end{abstract}

Keywords Glottodidactics, Teaching Arabic, Cultural Competence, Intercultural Communication

\section{Introduction}

Characterizing the notion of the cultural concept in teaching Arabic as a foreign language, one should notice in the first place, that both Polish and foreign publishing market offer but a few publications dealing with the theoretical aspects of the didactics of this language. It is worth to mention the publication written by Norbert Tapiero Pour une didactique de l'arabe moderne, langue de communication: problématique et solution (1976), which discusses the modern concepts and methods of teaching Arabic - these concepts replaced the grammar-translation approach which had been most common lately. Polish publications regarding this subject include: Dydaktyka języka arabskiego [Didactics of Arabic] by Elżbieta Górska and Marek Skoczek (1999), Nauczanie języka arabskiego [Teaching Arabic] by Iwona Król (2005) and the collective works edited by Magdalena Lewicka and Barabara Michalak-Pikulska: Dydaktyka języka arabskiego. Teoria - praktyka - perspektywy [Didactics of Arabic. Theory - practice - perspectives] (2013) and Dydaktyka języka arabskiego. Rozwijanie receptywnych sprawnosici językowych [Didactics of Arabic. Development of the receptive language skills] (2014).

The authors of the above mentioned works indicate the necessity of developing the cultural competence and the skill of the intercultural communication and so, the analysis of the Arabic language teaching curriculum prepared by Górska and Skoczek leads to the conclusion that the presentation of the cultural and realities issues is an important element even at the basic level. What is more, it is important to emphasize the specific character of the cultural territory where the language is used as a communication tool. In line with the concept discussed by the authors of Dydaktyka, the competence should be developed, complemented with new elements added at the subsequent stages of learning in order to achieve the "ability to identify and to interpret the cultural and religious specification of a given country and the socio-linguistic context" [1]. Additionally, the authors of the discussed publication indicate that "the objective of learning consists in mastering the contemporary oral and written literary language, paying special attention to the specifics of the cultural circle" [2]. In his paper, Król also indicates the essential meaning of introducing the elements of communication competence to the process of the acquisition of a foreign (here: Arabic) language which also includes the cultural competence allowing "the adequate behaviour (verbal and non-verbal) towards the persons belonging to a specific language circle in various communication situations" [3].

To a larger extent, this issue is discussed by Lewicka in the 
paper entitled Kompetencja kulturowa i komunikacja interkulturowa w dydaktyce języka arabskiego [Cultural competence and intercultural communication in the didactics of Arabic] [4] where - starting from the evolution of the concept of the language competence in glottodidactics - the author presents the definition of the (inter)cultural competence and then progresses to the description of the methods of teaching Arabic with the elements of the realities and culture and, what follows, the ways of presenting these issues in the didactics of a foreign language as well as the assumptions of CEFR (Common European Framework) within this scope, including the cultural and realities studies content the acquisition of which should be correlated with teaching a foreign language at particular stages of education. As the author indicates [5]:

For many years European glottodidactics have been postulating linking the practice of teaching foreign language with the presentation of the realities and culture which resulted in the development of the new glottodidactic sub-discipline known as intercultural glottopedagogy and the set terms such as: die Landeskunde (German), area studies (English), la civilisation (French), la civiltà (Italian) or stranovedenie (Russian). The lack of a similar term referring to the didactics of Arabic and the aspect of exposing the students to the Arabic (or, to be more specific, Arabic and Muslim) culture and making them aware of the intercultural differences does not mean that teaching Arabic should not be strongly embedded in the cultural context. For in spite of the fact that in the currently dominating communication approach the key objective consists in the ability of efficient communication, there is no doubt that lack of the intercultural competence may contribute to threatening the efficiency of the communication in a given language.

\section{Materials and Methods}

The subject of the undertaken research: Characteristics of the cultural and realities curriculum for Arabic language area. Cognitive objective of the research: specifying the need of correlating the language teaching curriculum with teaching the realities and culture of a given language area.

Practical objective of the research: creating the cultural and realities curriculum for teaching Arabic.

Key research problem: Should teaching Arabic as a foreign language be correlated with teaching the realities and culture of a given language area.

Detailed research problems:

- What is the place and function of the cultural and realities content in the foreign language teaching curricula;

- What are the concepts of teaching the cultural and realities content in the foreign language teaching curricula;

- What cultural and realities curricula function within the foreign language teaching curricula;

- Which principles should be applied to the process of designing the cultural and realities curriculum for teaching Arabic as a foreign language.

Key hypothesis: Teaching Arabic as a foreign language should be correlated with teaching the realities and culture of a given language area

Detailed hypotheses:

- The cultural and realities content plays particularly significant role within foreign language teaching curricula;

- Teaching the cultural and realities content within foreign language curricula can take place following various concepts, such as cognitive (factual), communicative, intercultural or eclectic;

- The culture and realities curricula included within foreign language teaching curricula should contain clearly and strictly defined elements;

- The culture and realities curriculum for teaching Arabic as a foreign language can be designed on the basis of the similar curriculum for teaching Polish as a foreign language.

Research methods used: heuristic, analytical, phenomenological and hermeneutic.

\section{Cultural and Realities Studies Curriculum in Teaching Polish as a Foreign Language}

Currently, the issue of the place and role of the cultural and realities components in the curricula of Polish as a foreign language is a well-researched and widely characterized matter in numerous scientific and popular-science publications. However, only in 1992 Joanna Fabisiak [6] indicated in her paper the lack of textbooks and curricula including not only the extensive but at least sufficient discussion of the subject. This statement is true even in the light of the fact that in the result of research and observations on the issue it was proven that the history of the description of cultural components connected with Polish language area reaches in its origin as early as $16^{\text {th }}$ century with Wokabularz rozmaitych $i$ potrzebnych sentencji... [Vocabulary of various and necessary sentences...], however, throughout the span of centuries the content was not extended sufficiently [7].

In the quoted paper, Fabisiak discusses the first drafts of the compendium of Polish culture - "Polonicum" developed by the Instytut Języka i Kultury Polskiej dla Cudzoziemców. The draft was to include ten major ideas such as: Poland (the picture of the society at a given moment and its development area), the regions, language, history, relics of literature, literature for children and youth, customs and traditions, 
folklore, monuments and the personalities and peculiarities of Polish political culture. The authors of the project attempted to present various elements of Polish cultural reality, from the most important events in the history, throughout the best-known literary works and most valuable relics of art, to the most characteristic natural phenomena, basics of geography and calendar of public holidays [8]. This work is one of the first proposals of the cultural corpse for teaching Polish as a foreign language - the list of currently available publications, based on a defined curriculum is much longer.

Polish publishing market offers the foreigners a number of publications on Polish culture as well as textbooks for teaching Polish as a foreign language introducing the elements of realities on various teaching levels [9]. Some of these projects were based on the experience of Polish language teachers working in foreign institutions and scientific centres, while others (for example the one written by W.T. Miodunka) were developed on the basis of similar programs prepared to cater for the needs of the didactics of other languages, mostly English and Russian.

Curricula based, to a large extent, on the criteria formulated by the Council of Europe in CEFR [10] have also been formulated. This publication, apart from introducing the description of the skills mastered by a learner on various levels (basic user A, divided into breakthrough or beginner A1 and way stage or elementary A2; independent user B consisting of threshold or intermediate B1 and vantage or upper intermediate $\mathrm{B} 2$; proficient user $\mathrm{C}$ effective operational proficiency or advanced $\mathrm{C} 1$ and mastery or proficiency $\mathrm{C} 2$ ) review of ideas on the curriculum forming the foundation for the development of a language course and didactic materials also emphasizes the role of the so-called intercultural sensitivity, playing a significant part in the process of learning foreign languages. The authors of the CEFR aimed at facilitating the improvement of the linguistic education within the area of the linguistically and culturally diversified Old Continent in line with the assumption that the "rich heritage of the variety of languages and cultures in Europe is a precious, common value which has to be protected and cultivated" and the "main educational effort of the member states should be directed at transforming the diversity into the source of mutual understanding and cultural enrichment in the result of defeating the communication barrier" [11], hence, the issues connected with the cultural and realities studies occupy an important place here.

One of the concepts of presenting the elements of culture in the process of teaching Polish as a foreign language is based on the theory of Robert Galisson (professor of linguistics and didactics of teaching French as a foreign language at Sorbonne Nouvelle University), adjusted to Polish language. The theory assumes the introduction of lexiculture, or specific vocabulary marked by a certain cultural body of a given community; the other name of lexiculture is, for example, linguiculture [12].

Wojciech Jekiel notes that for teaching and learning Polish as a foreign language the knowledge covering cultural studies is important due to the character of the language Polish (similarly to Arabic) does not have the "congress" character which means that its new users usually do not learn it for the needs of communication, but more often because they are interested in Poland as a country, rather than in the language [13]. The importance of being familiar with Polish reality and its characteristic features (so called "low culture") and the "high culture" is emphasized by the statement made by Hélène Włodarczyk: "In order to understand an utterance in Polish, one should not only be aware of the principles of the language, but also be a little familiar with the geography, history, literature or even cuisine, in fact all the things that form a given culture and differentiate it from its neighbours" [14].

However, it is necessary to diversify the cultural content of the classes of Polish as a foreign language (this is also true for other foreign languages) which practically means introducing the issues regarding not only the "high culture" (so-called factographic approach) but also the popular, mass culture people are exposed to in daily life (so-called intercultural approach). This is noted by Piotr Kajak, for example. Kajak in his paper indicates that "teaching popular culture does not mean that the high canon should be forgotten. It is necessary to teach both - one cannot exist without the other" [15], for "in the world dominated by the popular culture it is impossible to live without it" [16]. Nevertheless, the assumption that socio-linguistic (socio-cultural) competence relies not only on strictly factual approach but also concern the language skills of communicative character directly connected with the practical usage of a language, has significant meaning.

Jekiel distinguishes three methods of introduction of the cultural and realities content right at the early stage of teaching Polish as a foreign language: the first of them consists in including them in the introduced vocabulary, grammar and preformed exercises; the second one is based on presenting the issues connected with culture and daily customs with the specific Polish forms of the colloquial language; the third method is connected with making the new users of the language familiar with the content covering Polish culture in the form of a discussion, reading various texts, papers, etc. [17].

The selection of the didactic materials, including the textbooks which are acting as guidebooks of a kind, has an essential meaning. Such textbooks should provide guidance not only on the language as such, but also on the social and cultural reality of a given community. Their importance for the didactic process is emphasized by the statement of Marian Górecki "The textbooks act as intermediaries between the listener and the culture of the taught language. Hence, it is essential that cultural content is present in the textbook and not only beside it, as an additional material" [18].

Curriculum proposed by Professor Władysław Miodunka, Polish philologist, pioneer of Polonistic glottodidactics, member of the staff of the Centre of Polish Language and 
Culture in the World of Jagiellonian University, seems to be particularly interesting in this field. The curriculum was presented in the paper published in Culture in teaching Polish as a foreign language. Current status - curricula didactic auxiliary material [19], is constructed on the basis of such corpses as: Threshold level 1990, Porogovyj uroven'. Russkij jazyk; and on the basis on the guidelines of CEFR. It consists of two main segments: A and B and refers to the threshold, basic level of teaching Polish as a foreign language. Segment A directly regards the socio-cultural competence and in three sections discusses the communication based on: verbal contact, communication without the words or on the social rituals (paying visits, offering food and drinks, customs and ceremonies of various kinds). Module B in turn, covers the knowledge on Poland and Polish nation and in line with the guidelines included in CEFR draws the learners' attention to the issues such as the basic information on geography of the country, characteristic features of Polish society of the second half of $20^{\text {th }}$ century up to the integration with the EU, national identity of Poles, the role of religion and the status of the family. It also accommodates the Polish community living abroad and the facts regarding foreigners living in Poland.

If the curriculum developed by Władysłam Miodunka is to be presented by each item, one by one, segment A includes: the module of verbal contact - ways of introducing oneself and other persons (directly, over the phone in correspondence and e-mails); definition of the level of intimacy and addressing method (directing the utterance to friends and strangers, colleagues, acquaintances); expression of the social distance through the language (qualification of the restraint or lack thereof by using polite forms or indicating politeness and good manners as values of the Polish culture, social meaning of getting onto first-name terms); finally, paying complements and Polish savoir-vivre. As far as non-verbal contact is concerned, Miodunka distinguishes: body language (shaking hands, kissing women's hands, kissing and hugging, touching the interlocutors, gestures), eye contact, facial expression and the personal bubble. The third segment of the curriculum of cultural competence sensu stricto deals with paying visits (time, being on time, having guests, dress-code and behaviour); customs connected with eating and drinking (in daily life, at work, during parties of various type, it also defines the times of the meals); subjects of conversation (without distinguishing intimate and general, universal subjects, but with the specification of the awkward subjects); customary behaviour patterns (also during festivities of various kinds - religious, family, such as birth, wedding, death).

Segment B of the cultural curriculum for Polish language described above aims at introducing the information on Poland and its society. In the first place it characterizes the information regarding the geography (borders, key regions, cities, places of interest) and Polish nation (with the historical division including the functioning of the nation in the communist Poland and after the transformation). Next, the national identity is mentioned, as well as the roles played by the religion and family in the lives and attitudes of the Poles. Also, the functions of municipal and rural live in the Polish mentality are discussed. Finally, the segment contains the information on folk and regional culture, Polish community living abroad, foreigners in Poland and the position of Poland as a member of the European Union [20].

The fundamental difference between the two modules of the curriculum for the socio-cultural competence of Polish as a foreign language consists in distinguishing the issues which are strictly linguistic (segment A) and factual (segment B). Miodunka's draft includes, thereby, two basic issues forming the cultural and realities studies component allowing the efficient development of the cultural competence in teaching a foreign language. It constitutes a coherent binding of strictly linguistic skills and the knowledge of the realities, facts (regarding both high and low culture). It is a sketch of a curriculum in the form of the list of themes which should be presented as specific information and exercise during classes of foreign language, to be introduced on the threshold level of teaching Polish. The list allows quite detailed definition of the content which should be included in the cultural curriculum to be realized practically.

\section{The Outline of the Cultural and Realities Studies Curriculum in Teaching Arabic as a Foreign Language}

Although CEFR was developed with European languages in mind, on the plane of the socio-cultural issues it raises important matters for the process of the development of the linguistic skills not only in the case of the countries of the Old Continent but also of the countries in the other parts of the world. Hence, the curriculum for cultural and realities studies in teaching Arabic as a foreign language (further referred to as AFL) presented in this paper is based on the CEFR guidelines and, additionally, on the cultural corpses developed by the glottodidactians and linguists specializing in teaching Polish as a foreign language, and also on the author's observations regarding the widely understood Arab and Muslim culture.

The list of the issues presented below is the resultant of the key elements of the culture ( $a \underline{t}-\underline{t} a q \bar{a} f a)$ and realities $(a l-w \bar{a} q i$ ) of the Arab world, coherent in its multi-culturality, dubbed by the Arabs themselves Al-Watan al-'Arabī, or the "Arab Fatherland"; this name suggests the custom integrity. The essential role of such a cultural program has been emphasized on numerous occasions by the theoreticians and practitioners of teaching Arabic in Poland, for example by Michał Moch who in Didactics of Arabic... claims that the "student starting to learn Arabic needs to assimilate the essential cultural context" [21] or Magdalena Lewicka who indicates the "necessity to include the socio-cultural factor 
and to develop the intercultural competence of the learners" [22].

The proposed cultural corpse for teaching AFL on A1-A2 level (the registry known as al-fușhà or Modern Standard Arabic is referred here) constitutes the synthesis of the knowledge about the world, socio-cultural knowledge and also of the strictly socio-linguistic competence, or the correct usage of language in the situation embedded in the specific cultural context. In practice it means the knowledge of the determinants of the social relationship (addressing, welcoming forms), polite forms, the carriers of the "lore" (fixed language phrases) and also the registry of the utterance, dialects, variants of the language with the knowledge on the realities and the world of the community whose speech is the subject of learning. Hence - following Miodunka in reference to Polish as a foreign language - it is justified to divide the outline of the cultural curriculum into two basic parts: the first part regarding strictly socio-linguistic competence (or language skills accompanied with the knowledge on the standards of behaviour) and the second part which shall refer to the section including the cultural knowledge (also, the knowledge of the society and the customs of a given community).

The first part of the outline for the cultural curriculum for the AFL contains, therefore, strictly linguistic elements (which aid the linguistic communication as such) and also the ones regarding the non-verbal communication and the rules for functioning in the Arab society. In other words, these will be the subjects connected with the behaviour linguistic and social as well. This part, however, does not include the elements of the strictly factual segment which constitutes the basis of the subsequent module of the curriculum outline. Bearing in mind the fact that the outline regards the basic level of the language, it presents the fundamental issues leading to the efficient mastering of the Arabic from the point of view of the socio-cultural/socio-linguistic competence.

\subsection{The Outline of the Cultural and Realities Studies Curriculum Included in AFL - Module A}

In reference to the module A of the outline of the cultural and realities studies curriculum correlated with the practical teaching of AFL, when one considers the guidelines of the CEFR, the learner on level A1-A2 "can understand and communicate simple routine tasks (...) can (...) interact in the social conversations (...) using the typical polite welcoming and addressing forms (...), can formulate an invitation, proposal, apology, etc., and react to the above expressions (...), can establish the basic social contacts (...)" [23], however, the above regards the basic forms, easy to form and express, quite often the popular ones and those referring to the fixed conversational phrases. Considering the specification of the Arabic language area, the curriculum outline mostly contains the items concerning the MSA registry (al-luḡa al- 'arabiyya al-fushà), yet, it does not exclude the socio-linguistic references regarding the most important, best known and most common dialects (al-lahağa $t$ ). At this place one can see the great importance of diglossia (al-izdiwāăgiyya al-luğawiyya) in the Arabic world - the phenomenon which cannot be omitted in the linguistic matters. The further parts of this paper shall list the elements of the outline of the Arabic cultural and realities studies corps as proposed by the authors, including their brief comment to each of the items in order to provide the more detailed explanation of their assumptions and aims to be reached in the course of the practical learning of the AFL.

Module one, or part A called "Strictly linguistic skills"(al-mahārāt al-luḡawiyya bi-l-hașr) begins with the segment of the verbal contact, which in turn contains the "Beginnings" (Al-Bidāyāt) and regards the formation of the contacts between people, the basic language structures used in the earliest phase of the conversation and discusses the polite forms (ta 'ābir āt al-lutfi) used in such conversations. It also contains expressions for making acquaintances (at-ta 'âruf) and the polite forms of greeting (at-tahiyya), making introductions (taqdim an-nafs) and saying good-byes $\left(a_{\text {t-tawd }}{ }^{\circ}\right)$ which are involved in the process. Hence, in Arabic the basic expression used for welcoming is the customary مرحبا! Marhaban! ("Hello!", the expression can be used on various levels of acquaintance), أهلا! Ahlan! (“Welcome!"), ! صباح الخير Sabāhu al-hayr! ("Good day!” used in the mornings), أهلا وسهلا Ahlan wa-sahlan! ("Welcome cordially!"), مساء الخير Masā'u al-hiayr! (“Good evening!"- the expression used in the afternoon and evening). One should also note other polite expressions related to greeting, such as كيف حالك؟؟ Kayfa hāluka/ki? ("How are you?”), هل أنت بخير YHal anta/anti bihayr? (“Are you fine?”) that provoke the reaction in the form of the adequate reply and reverse question. As far as saying good-byes (at-tawdī) is concerned, one can list the following expressions: مع

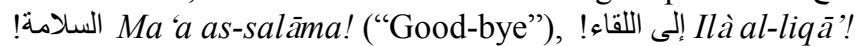
(Good-bye!”), ليلة سعية Layla sa 'idla! (“Good night!”). Another item on the list concerns the expressions used to introduce oneself and the others (at-taqdim). This includes the customary expressions used in each language, such as: "My name is..." (اسمي Ismī ...), "I am..." (أنا Anā ...), This

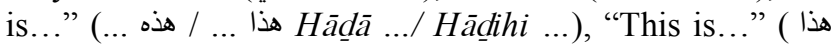

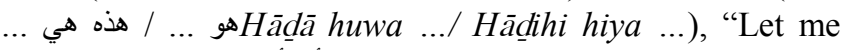

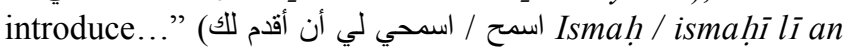
uqaddima laka / laki ...), etc. However, one should also note various forms of the name (al-ism) used in Arabic, that is the traditional introduction of oneself as "mother/father to a child" when one is a parent (al-ab, al-umm) - it the Arab world the interlocutors replace their real name with the expression such as أم/ أبو خالد Umm/Abū Hâlid, or "Mother/Father of Hālida". Signalling this phenomenon in the course of learning is essential due to the fact that it fundamentally differs from the Polish expressions used to introduce oneself and to give names. One should also mention the other contextual polite forms used in the communication situations of this type, for example: تشرفنا Tašarrafnā ("I am pleased to meet you."). 
Another item included in this segment is entitled "Further contacts"(Al-ittisāl al-awsa ): the Arabic specification of calling people (at-taqaddum), addressing (al-alqāb), taking turns in speaking (al-kalām) in various situations and using the exclamation forms (istihldām ta 'ābirr at-ta'ağğub). While presenting the expressions connected with starting a conversation one should mention that in Arabic the interlocutor is usually addressed with the colloquial "you" أنت/أنت anta/anti. This is the most common addressing expression which bears no negative emotional load, with the exception of the fixed phrases and official conditions. When the latter are mentioned, the language classes on the threshold level should include the expression such as Yà sayyidī, sayyidatī,... ("Sir/Madam”). Besides, the cultural corpse should include the forms which are specific

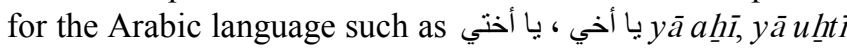
("brother" or "sister") which are used in relation to the various persons independently of the level of kinship (these expressions, however, are only used by Arabophones, they are not usually used by non-native speakers), با حاج yāh hăğgi ("pilgrim") - in relation to a person who has just been on the pilgrimage to Mecca, but also, when addressing an elderly person, با حبيبي yā habỉbī (“dear”) - the role and relationship similar to يا أخي yāahī. As far as taking turns in conversation is concerned, one should mention the expression لو سمحت law samaht ("with your permission”, "I beg your pardon”, “excuse me”), من فضلك min faḍlika/ki (,,proszę”), or آسف/آسفة" āsif/āsifa ("I'm sorry"), عفو ا" 'afwan ("please", "excuse me"). تفضل/ When somebody grants us permission they usually say tafaḍdal/i ("please", "go on"). In case of the exclamation forms, the essential forms to be mastered are the ones which are linked to Islam (one should note a strong presence of religion in the linguistic acts), for example: ألها Wa-Allahī! ("By God (Allah)!"), أللهم Allāhumma! (“Oh God!"), إن شاء أله. In šā'a Allāhu. ("If God wills") etc..

Another issue included in the scope of the "Strictly linguistic skills" (al-mahārāt al-luğgwiyya bi-l-hasri) is the presentation of the polite expressions and conventions ( $t a$ 'âbir àt al-lutf). They play particularly important role in the intercultural contact since, de facto they condition the quality of the further communication. Nonetheless, regarding the analysis of the issues on the threshold level presented in this paper and the specific complexity of Arabic, the matter can be limited to the essential minimum. The general function of the "politeness" (dawr al-lutf) in contacting the Arabic communities - just as in the case of other languages - is showing the interest in the well-being of the interlocutor, expressing the admiration and appreciation (for example during the conferences or presentations of various types, when one wishes to ask the speaker a question, they should express gratitude for the "excellent speech"). Similarly to the communication in other languages one should avoid orders and being pushy and - if necessary express the apology, grief or sorrow. In this place one can mentioned the expressions quoted above, such as: من قضلك

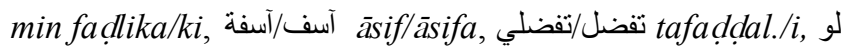
law samaht, but also شكمت Šukran ("thank you") and additionally forms used to express the consent or confirmation (و والتأكيد الموافقةal-muwäfaqa wa-at-ta'kid) as well as denial and negations: (النفي والرفض an-nafi wa-ar-rafḍ).

Another item in the segment including the verbal contact is "the lore" (al-ḥikam a ̌̌-ša biyya), or the idioms (at-ta 'ābir al-iṣtilāḥ̂̀), popular quotes (al-aqwāl) and proverbs (al-amtâal). At the threshold level, these questions can be limited to the most common phrases. In Arabic they should include - mentioned previously when discussing the exclamations - the phrases containing religious elements, but commonly used, regardless of the level of the religiousness, age, membership in a given social group, for example: إن شاء أله. In Šā'a Allāh. ("If God wills”, today a very common phrase expressing hope that something will happen), but also: هيا! Hayyā! ("Go on!", in the meaning

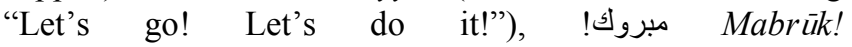
("Congratulations!").

The final elements of the section regarding the verbal contact includes: the ability to recognize the register, variation of a language and the general presentation of the basic dialects. On the threshold level of the language, the neutral register is usually used; however, getting the students familiar with the methods of recognizing the degree of formality might become useful.

As far as the regional variations of the language are concerned, the students should be made aware of the fact that Arabic is a complex language system consisting of many dialects (more information regarding the Arabic linguistic situation can be found in: Lewicka [24] and Danecki [25]; information regarding the Arabic dialects can be found in: Machut-Mendecka, Pachniak [26], Machut-Mendecka [27], Benmamoun [28], Danecki [29]) - some basic words of the Egyptian dialogue may be introduced here as a trivia (for example from: Behnstedt [30], Semsek [31], Olmsted, Gamal-Eldin [32], Mitchell [33], Tomiche [34].

The next segment of the module "Strictly linguistic skills" includes the non-verbal contact (al-ittṣāl ğayr šafahî), referring to the behaviour (tasarruf) and body language (luğat al-ğasad). Particular attention should be paid to the function of the distance between the interlocutors of various sexes, especially in contacts with religious persons. It should be emphasized that women may experience a non-returned hand shake by a Muslim male or even the lack of the eye contact (and vice versa, a Muslim women avoid shaking hands with males and looking into their eyes), however, when more advanced relationship is concerned, the physical contact will be more common - the Arabs have no problems with physical contact in the case of people they know more or less (we are talking about the representatives of the same sex). The new users of Arabic should also be made aware of the fact that the rule of maintaining certain distance between the interlocutors will vary in relation to the geographical location (for example, the citizens of Saudi Arabia are more 
restrained than people living in the countries of Maghreb or Levant) while the eye contact is considered as a token of respect regardless of the location. Additionally, depending on the selection of the didactic materials and specific situation, the course of the classes of AFL can include the mentioning of the essential elements of the body language used in the Arab community, for example, placing a palm of one's hand on their chest by the heart as a token of respect (al-ihtirām), raising one's eyebrows or clapping the tongue as an expression of negation or denial (ar-raf̣̣), etc.

The last segment of this module is the part dedicated to "Customs" (al- 'ādāt) and it includes the social rituals ( $a \check{s}$-ša 'ã'ir al-iğtimā 'íy $y$ ). The classes of AFL may include several issues being of importance for the native speakers of Arabic. While introducing the matters regarding the visits, one should emphasize that in the Arab communities being on time (diqqat al-mawa ${ }^{`} \bar{i} d$ ) is characterized by time frames which are not strictly set which means that punctuality is not a very important element. The students should be made aware of the proper dress code for both sexes (al-malābis) and of the fact that in some circles a woman might be separated from a man during the visit. As far as the eating ( 'àdāt al-akl) and drinking ('āa āt $a \check{a}$-šsurb) is concerned, an important element consists in indicating the social dimension of the role played by tea ( $a \check{s}$-šăy) as a symbol of hospitality ( $a$ d - diy $\bar{a} f a$ ), and also enticing the guests to try some food (in the end the proposal should always be accepted, it is impolite to decline). It is worth to pay some complements to the host after the meal is over. One should also mention here the rule of using only one's right hand for eating and drinking (the rule of the impurity of the left hand) and the fact that Muslims do not eat pork (lahm al-hinzir) nor drink alcohol (al-kuhūul).

\subsection{The Outline of the Cultural and realities Studies Curriculum Included in AFL - Module B}

While the part of the cultural corpse refers largely to the socio-linguistic issues, module B regards strictly factual knowledge. It presents the most important themes linked with the knowledge of the culture (at-taqāfa) and realities (al-wāq ${ }^{\circ}$ ) of the Arab world which should be possessed by the new users of the language. Familiarity with the Arab culture is all the more essential element of learning AFL that without it the learners will be unable to communicate the native speakers efficiently and coherently. The Arab culture is the basis for each social phenomenon in this area.

As it was emphasized previously, there are cultural elements which unify the Arabs in an imperative way which is particularly important in the course of mastering Arabic. Quoting Marek Dziekan [35] "they are mostly united by the cultural uniformity: they will all refer to the common history and language". On A1-A2 level the knowledge of the common component for all the Arabs - regardless of their affiliation with other larger or smaller communities or cultural circles resulting from the geographical location for example - is not very vast and does not include all the key issues. However, it does form a foundation facilitating the communication in Arabic, but at the same time requiring expansion and completion on the subsequent stages of learning.

The first item on the list included the basic information

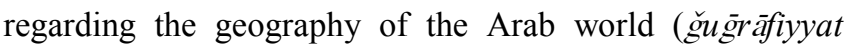
al- 'allam al- 'arabi). Mostly, it regards the knowledge of the Arab (al-buldān al-'arabiyya) and Muslim (al-buldān al-islāmiyya) countries and the ability of distinguishing them (following the rule Arab country $\neq$ Muslim country), locating them in the political map of the world as well as indicating the capital cities and politically, socially and economically most important cities (al-mudun) regions (al-manātiq) and also geographical regions (al-manātiq) with rivers, mountain ranges and lakes (al-anhārr/al-ǧ̈ibāllal-buhayrāt).

Two or three initial issues will always be presented in the same way (all the data is non-changeable and is included in the scope of the general knowledge), however, the selection of the cities and geographic regions is, to a large extent, of a subjective nature. Nevertheless, due to historical, economical and political conditioning, more attention should be paid not only to Cairo (Al-Qähira), Damascus (Dimašqu) and Baghdad ( $B a \bar{g} d \bar{a} d)$ as the most important capital cities, but also to Jerusalem(Al-Quds) on the grounds of the historical and religious conditioning; to Dubai (Dubayy) due to its role in the modern economy; to Mecca (Makka), on the basis of its religious meaning, particularly significant in the Arab world. As far as the elements of the geographical map of the Arab world (Al-Watan al- Arabï) are concerned, the AFL classes should include information on the river Nile (Nahr an-Nïli) and Jordan (Nahu al-Urdun), the problem of the nomenclature of the Persian Gulf (Al-Halīg al- 'Arabì), the historical meaning of Euphrates (Nahr al-Furāt) and Tigris (Nahr ad-Diğgla), Sahara Desert (As-Sạ̣rā'al-Kubrä), Atlas Mountains (Ǧibāl al-Ațtās), location of the Golan

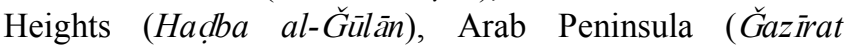
$a l$ - Arab), explanation of such terms as Fertile Crescent (Al-Hilāl al-Hașïb) and the Levant (Bilād aš-Šàm), etc. One should also point out that the learner who is looking at the political maps published by the Arabs will not find the country of Israel on them, due to the fact that the Arab world does not recognize its existence - on the map, the borders of Jordan cover the space to be taken by Israel.

Another item in this section of the corpse is the historical element (al- unșur at-târịhîh). Presenting the basic history of the Arab world (or as a whole, the history of the Arab and Muslim civilization) in this place is very difficult due to the vast nature of the subject, however, one can - and should define several important stages in the history. One of these subjects includes, for example, the characteristics of the native Arabs, the Beduin ( $A l-B a d \bar{u})$ due to their influence on the current condition of the Arab community and the features it inherited from its predecessors. It is worth to mention the presence and the achievements of the two most important dynasties in the history: the Umayyads (Al-Umawiyyün) and the Abbasides (Al- 'Abāsiyyūn), the meaning of the Muslim 
Spain (Al-Andalus), revival of the Arab world at the turn of the $19^{\text {th }}$ and $20^{\text {th }}$ century (an-nahda al- 'arabiyya). The history of Islam is also an obligatory element of the segment dedicated to history. At this stage of learning AFL one should become familiar with the facts connected with the shaping of this religion and its expansion throughout the centuries. Here, it is good to mention the important historical figures such as prophet Muhammad (Muhammad), great leader and politician - Saladdin (Salāh ad-Dinn), etc.

The third part of this module, resulting directly from the previous one, is the role of Islam (al-islām) in the Arab world. Apart from its historical outline it is also essential to emphasize the importance of the Muslim religion which influences nearly each and every aspect of the Arabs' lives. When introducing this subject in AFL classes, the key meaning is assigned to the knowledge of the basic information on the Muslim customs and traditions and the basic doctrinal issues including the dogmas ('aqā'id al-islām), that is: the faith in one and only God, the angels, holy books, prophets, the Judgement Day, the five pillars of faith (arkān al-islām), namely: the Shahada (faith, $a \check{s}$-šahada), the prayer (aș-șalāt), the charity (az-zakāt), fasting (as-sawm), the pilgrimage to Mecca (al-hağgg $)$; the source texts, namely: The Quoran (Al-Qur'ân) and Teachings (As-Sunna); the basic variants (at-tawāif

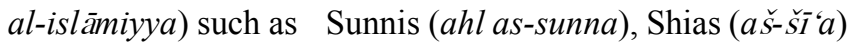
and Kharijite (al-hawāriğ); the most important holidays that is Eid al-Fitr (festival of breaking of the fast, 'Id al-Fitr) and Eid al-Adha (festival of the sacrifice, 'Id al-Aḍcha); also the rules regarding the dress code - which parts of the body should be covered and how to use the Muslim veil (al-hiğăb). Additional information should include the statistical data regarding the number of Muslims in the world and the key Muslim centres on our planet. It is also worth to characterize the perception of Islam by non-Muslim regions, particularly by Europe and America, discussing the stereotypes functioning in these communities (Muslim - terrorist, jihad the holy war, Muslim woman - enslaved woman, etc.).

The next segment refers to the Arab society (al-muğtama * al- 'arabî), namely - its structure (al-haykal), patriarchal organization (at-tanzīm al-iğtimā̄î̀), social classes (at-tabaqāt al-iğtimā îyya) existing in this society depending on the country that is discussed (for example: United Arab Emirates, Qatar - mostly high and medium class due to the high GNP); the division into the women's and men's spheres (al-maydāna al-untawì wa-ad-dakarì). One of the issues worth to be discussed here is the identity of the Arabs: unity (at-wahda) in the Arabic homeland, the feeling of belonging, community through the common language and some political aspects (pan-Arabism, al-wahta al- 'arabiyya). The corporate factor of the Arab society should also be emphasized here - the good of the general society $(a l$ - 'amma $)$ is more important than the good of an individual (al-wahda). Another, clearly visible feature is the increasing general dissatisfaction of the Arab people with the political and economical situation of their countries which is reflected in the theme of the Arabic Spring (Ar-Rabī'al- Arabì) and numerous unrests. The problem of meeting and confrontation between a deeply rooted tradition (at-taqlïdiyya) with modernity (al-hadāta) seems to be an interesting subject for discussion. It may include the presentation of the issue of values (qiyam) and the attitudes of the presented community: courage ( $a \check{s}$ šsa $\left.\check{s}^{\prime} \check{a}^{\prime} a\right)$, hospitality (aḍ-diyāfa), religiousness (ad-diniyya) or the openness (al-tafattuḥ), generosity (al-kirāma) and honour ( $a$ šššraf). It is also important to make the learners aware of the fact that the Arabs hold the aging and the elderly in high esteem and respect them. Elderly persons are usually identified with wisdom (al-hikma) - yet another cultivated and respected trait of character.

From the section regarding the society, one can progress to the issue regarding the meaning of the family (al-usra)

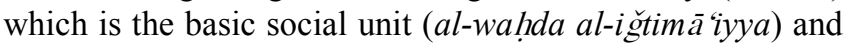
constitutes the basis of the Arab identity. At this point one should discuss the role played by parents (al-wāladān), the institution of marriage (az-zawăg) including the planned marriage and the difficult way leading to the exchange of the vows, the essentiality of having children (al-awläd), in this case, the more, the better (this reflects the fertility of a given family, a key attribute in the Arab community). The values which are trasferred from generation to generation are very significant and lasting in the Arab society: strong feeling of belongingness (al-intimā) within the family, defending the family's honour ( $a \check{s}$-šaraf), also the wealth inheritance law (al-haqq li-l-wirāâta).

It is worth to mention that Islam strongly influences the functioning of the family (for example, the allowed number of wives, the roles of males and females as the spouses and parents); and the changes which are taking place in the Arab world's society and the structure of the hearth and home due to the influence of the West.

Widely understood customs (at-taqâlièd) are closely connected with the issues mentioned above. Due to the limits of time and language at this level of advancement, one should treat this issue selectively and include the presentation of the most important customs. The Arab cuisine (al-matbah $a l$ - 'arabîl) enjoys the well-earned interest, followed by the oriental dance (ar-raqs aš-šarq $\overline{1}$ ) and calligraphy (al-hatt al- 'arabî). From the point of view of the religious tradition this scope incudes the recitation of the Quran (Al-Qur'ân), while the fusion of the Arab and Muslim tradition consists in the issue of the dress code (al-malābis) in the region of Al-Watan al- Arabī. The issues connected with the traditional outfit of this region of the world, the custom of covering women's heads and the type of the headwear used by women should be discussed along with the role of the make-up and jewellery used by women and the characteristic clothes used by men. While discussing the customs, the teacher can introduce the issue of the legendary Arab and Muslim figures (apart from Saladin and prophet Muhammad they include for example ' $\bar{A}$ ' iša, the best known of the Prophet's wives, 'Antar - a pre-Muslim poet and the model old-Arab knight, etc.) and the symbols of this culture (among others, hamsa, šiša, tea, camel). 
Another matter included in this part of the corpse is the subject of the woman (al-mar'a) in the Arab world; the subject which is exquisitely broad and is the source of the stereotypes. First of all, the new learners of the AFL should be made aware of the fact that the Arab woman is in the first and foremost place a wife (az-zawğa) and a mother (al-umm). One must not forget the issues connected with women's modest attire and the general precept of modesty (at-tawāạ $u^{\circ}$, especially in the countries where sharia law $\left(a\right.$ šsari $\left.^{\prime} a\right)$ is applicable and where - due to the above mentioned legal matters - the position of woman differs from the other Arab countries. Apart from the traditional view to the female part of the Arab society, one should indicate the actuation of the woman's position and the modernization connected with the phenomenon of the "westernization" caused by the more intense exposure to the western culture and the following birth of the women's liberation movement. One should emphasize that the Arab woman is not only a wife to her husband and the mother of his children, but more and more often an independent social unit who, apart from her family, is concentrated on her own well-being, development and self-realization.

One of the final matters included in the cultural corpse of the curriculum of AFL on the basic level is the matter of the mass-culture (at-taqāfa al-ğamāi iyya) and the leisure time (waqt al-farā $\bar{g}$ ). As for the former, the Qatar TV station Al-Jazzira(Al-Ğazira) plays an important role acting as a new archetype of the communication in the Arab worls. To introduce some diversion to the classes one can signal the existence of the world-popular entertainment shows (barāmiğ at-tasliyya) such as the Arab Idol (it is also possible to show the students fragments of this show) and the soap-operas (al-musalsalāt), especially the Egiptian series, as the most popular ones. It should be mentioned that the Arabs usually spend their leisure time visiting their families (muqābalāt al-usra), cafes (al-maqāhi) which have an important social meaning, or play the traditional games (for example backgammon, barğgis). As far as the issues connected with the literary (at-taqâfa al-adabiyya) and musical (at-taqāfa al-müsíqiyya) culture are regarded, one should mention the traditional Arab quasida (al-qasāid $)$ and more contemporarily, the works of Adonis (Adūnis) or Najjib Mahfuz (Nağğb Mahfüz). The singers worth mentioning include the non-questionable icons of the Arab music - Umm Kulsum (Umm Kulțüm), Fayruz (Fayrüz), or currently Mašrū' Laylà and Nānsīi 'Ağram.

The final matter included in the outline of this curriculum is the issue entitled "Arabs in the world and the world in Arabs" (Al- 'Arab fīl- 'ālam wa-l- 'älam inda al- 'Arab). In the first part one should indicate the main directions of the Arab emigration, such as France, Quebec, United States, Spain (an other European countries located within the Mediterranean region - geographical conditioning), while in the second it is worth to mention the groups of the immigrants from the south and south-eastern countries who emigrate mostly to the oil industry countries of the Arab Peninsula. It is also worth to provide general characteristics of the Arab community on the emigration (religious, social, political issues and the functioning stereotypes).

\section{Summary}

There is no doubt about the fact that the development of the intercultural skills is closely connected to the particular stages of teaching a language. The failure to include the specific cultural norms by a foreigner uttering a message containing a number of mistakes will be taken by a native speaker with a certain dose of understanding. However, the skill of fluent and correct usage of a foreign language is usually linked with the expectations regarding the better knowledge of the foreign culture. On the basis of the guidelines formed in CEFR in reference to this area, the basic objective for the selection of the themes and taught content on the basic level is, on the one hand enabling a beginner student an efficient communication in daily situation and, on the other hand - developing a skill of expressing the basic communication intent. The essential element of the latter consists in the knowledge of the most important social and cultural conventions functioning in the communication in a given language. Hence, a successful graduate of the A2 language course should be able to participate in the social talks and organize their utterances in such a way that they are understood by other interlocutors regarding the language and socio-cultural criteria included in the scope of the verbal contact and social rituals. Additionally, the course graduate should know the basic facts on the country (countries) of a given language area, facilitating them the functioning in this country and understanding the patterns of behaviour, mentality and the identity of the citizens of this country [36].

The outline of the culture and realities studies curriculum to be used in the didactics of the AFL presented in this paper is designed for both the university courses and other courses at the basic level (A1-A2) in conjunction with the didactic and methodology assumptions regarding the presentation of the themes such as: the requirement of the active confrontation/discussion with the foreign cultures through the selection of the appropriate materials and methods of conducting the classes including the authentic content, various points of view and contradictions present in a given society, themes and historical texts providing the information on the bonds between the past, present and the future; referring to the traits of the foreign cultures in the learners' country; enticing them to creative work, invoking the curiosity and drive to discover something new, or strange. The role of the teachers in the realization of these assumptions has to be emphasized in this place, as well as the necessity of the teachers' education and professional improvement, cooperation in the preparation of the materials, mutual help in the scope of the didactics and methodology of teaching the realities and culture of a given language area which should be fully integrated with the practical teaching of the language. 


\section{REFERENCES}

[1] E. Górska, M. Skoczek. Dydaktyka języka arabskiego, Wydawnictwo Akademickie Dialog, Warszawa, 1991, 21.

[2] E. Górska, M. Skoczek. Dydaktyka języka arabskiego, Wydawnictwo Akademickie Dialog, Warszawa, 1991, 17.

[3] I. Król. Nauczanie języka arabskiego, Wydawnictwo Uniwersytetu Jagiellońskiego, Kraków 2005, 17.

[4] M. Lewicka. Kompetencja kulturowa i komunikacja interkulturowa w dydaktyce języka arabskiego, Dydaktyka języka arabskiego. Teoria - praktyka - perspektywy, Wydawnictwo Naukowe UMK, Toruń, 2013, 145-176.

[5] M. Lewicka. Kompetencja kulturowa i komunikacja interkulturowa w dydaktyce języka arabskiego, Dydaktyka języka arabskiego. Teoria - praktyka - perspektywy, Wydawnictwo Naukowe UMK, Toruń, 2013, 148.

[6] J. Fabisiak. Koncepcja kompendium wiedzy o kulturze polskiej dla cudzoziemców, Język, kultura - kompetencja kulturowa, Wydawnictwa Uniwersytetu Warszawskiego, Warszawa, 1992, 202-203.

[7] P. E. Gębal. Dydaktyka kultury polskiej w kształceniu językowym cudzoziemców, Universitas, Kraków, 2010, 64.

[8] J. Fabisiak. Koncepcja kompendium wiedzy o kulturze polskiej dla cudzoziemców, Język, kultura - kompetencja kulturowa, Wydawnictwa Uniwersytetu Warszawskiego, Warszawa, 1992, 204-206.

[9] W. Jekiel. Wiedza o kulturze polskiej na praktycznych zajęciach z języka. Część pierwsza - kurs dla początkujących, Vademecum lektora języka polskiego, Wydawnictwa UW, Warszawa 1992; C. Rowiński. Wprowadzanie elementów wiedzy o historii kultury polskiej i kulturze współczesnej Polski na lektoratach języka polskiego dla cudzoziemców (poziom średni i zaawansowany), Vademecum lektora języka polskiego, Wydawnictwa UW, Warszawa, 1992; B. Bartnicka, W. Jekiel. We learn Polish. An Elementary Course, Wiedza Powszechna, Warszawa, 1994; B. Ogrodowska, E. Piskorz-Branekowa, M. Ślusarska. Kalendarz polski. Historia i obyczaje, Wspólnota Polska, Warszawa, 1997; J. Nicklasson-Młynarska. Polish Direct. An Introduction to the Language and the Culture, Kursverksamhetens flag, Lund, 1998; L. A. Polakiewicz. Intermediate Polish. A cultural reader with exercises, Wydawnictwo UMCS, Lublin, 1999; O. Budrewicz. Polska dla początkujących, WAIF, Warszawa, 2000; R. Cudak, J. Tambor (ed.). Kultura polska. Silva rerum, Wydawnictwo Naukowe Śląsk, Katowice, 2002; A. Butcher, B. Guziuk-Świca, A. Laskowska-Mańko. Bliżej Polski. Wiedza o Polsce i jej kulturze, Wydawnictwa UMCS, Lublin, 2003.

[10] Council of Europe. Europejski system opisu kształcenia językowego: uczenie się, nauczanie, ocenianie, Wydawnictwa CODN, Warszawa, 2003.

[11] Council of Europe. Europejski system opisu kształcenia językowego: uczenie się, nauczanie, ocenianie, Wydawnictwa CODN, Warszawa, 2003, 14.

[12] B. Ligara. Leksykultura w ujęciu Roberta Galissona a nauczanie kompetencji kulturowej, W poszukiwaniu nowych rozwiązań. Dydaktyka języka polskiego jako obcego u progu XXI wieku, Wydawnictwo UJ, Kraków, 2008, 51-56.
[13] W. Jekiel. Wiedza o kulturze polskiej na praktycznych zajęciach z języka. Część pierwsza - kurs dla początkujących, Vademecum lektora języka polskiego, Wydawnictwa UW, Warszawa 1992, 165-166.

[14] H. Włodarczyk, Mot d'ouverture: de la linguistique théorique à l'enseignement du polonaise langue étrangère, Enseigner et apprendre le polonais langue étrangère, Centrum Polonicum, Centre de civilisation polonaise de l'Université Paris-Sorbonne, Paris-Warszawa, 2014, 21.

[15] P. Kajak. Kultura popularna w procesie nauczania języka polskiego jako obcego, W poszukiwaniu nowych rozwiązań. Dydaktyka języka polskiego jako obcego u progu XXI wieku, Wydawnictwo UJ, Kraków 2008, 297.

[16] P. Kajak. Kultura popularna w procesie nauczania języka polskiego jako obcego, W poszukiwaniu nowych rozwiązań. Dydaktyka języka polskiego jako obcego u progu XXI wieku, Wydawnictwo UJ, Kraków 2008, 297.

[17] W. Jekiel. Wiedza o kulturze polskiej na praktycznych zajęciach z języka. Część pierwsza - kurs dla początkujących, Vademecum lektora języka polskiego, Wydawnictwa UW, Warszawa 1992, 167-172.

[18] M. Górecki. Interkulturowość w podręczniku i na lektoracie języka polskiego jako obcego, Glottodydaktyka polonistyczna. W obliczu dynamiki zmian językowo-kulturowych i potrzeb społecznych, Wydawnictwo UMCS, Lublin, 2013, 146.

[19] W. T. Miodunka (ed.). Kultura w nauczaniu języka polskiego jako obcego, Universitas, Kraków, 2008, 97-117.

[20] W. T. Miodunka (ed.). Kultura w nauczaniu języka polskiego jako obcego, Universitas, Kraków, 2008, 111-114.

[21] M. Moch. Analiza źródeł historycznych i wypowiedzi politycznych jako element nauczania języka i kultury arabskiej. Dobór materiałów, krytyka źródeł i ich znaczenie w programach przedmiotów arabistycznych, Dydaktyka języka arabskiego. Teoria - praktyka - perspektywy, Wydawnictwo Naukowe UMK, Toruń, 2013, 112-113.

[22] M. Lewicka. Kompetencja kulturowa i komunikacja interkulturowa w dydaktyce języka arabskiego, Dydaktyka języka arabskiego. Teoria - praktyka - perspektywy, Wydawnictwo Naukowe UMK, Torun, 2013, 159.

[23] Council of Europe. Europejski system opisu kształcenia językowego: uczenie się, nauczanie, ocenianie, Wydawnictwa CODN, Warszawa, 2003, 109.

[24] M. Lewicka. Arabska sytuacja dyglosyjna i jej implikacje dla procesu rozwijania receptywnych sprawności językowych, Dydaktyka języka arabskiego. Rozwijanie receptywnych sprawności językowych, Wydawnictwo Naukowe UMK, Toruń, 2014, 63-82.

[25] J. Danecki. Współczesny język arabski i jego dialekty, Wydawnictwo Akademickie Dialog, Warszawa, 2009.

[26] E. Machut-Mendecka, K. Pachniak (ed.). Świat arabski. Kultura i polityka, Wydawnictwo Akademickie Dialog, Warszawa, 2012, s. 357-369.

[27] E. Machut-Mendecka. Kultura arabska. Mity, literatura, polityka, Eneteia, Warszawa, 2012, 186-188.

[28] E. Benmamoun. The feature structure of functional categories: a comparative study of Arabic dialects, Larousse, New York, 
2000.

[29] J. Danecki. Wstęp do dialektologii języka arabskiego. Wydawnictwa Uniwersytetu Warszawskiego, Warszawa, 1989.

[30] P. Behnstedt. Die ägyptisch-arabischen Dialekte. Bd. 3, 1, Texte. Delta-Dialekte, Ludwig Reichert, Wiesbaden, 1987.

[31] H.-G. Semsek. L'arabe égyptien de poche, Assimil, Chennevières-sur-Marne, 2011.

[32] G. J. Olmsted, S. Gamal-Eldin. Cairene Egyptian Colloquial
Arabic, North-Holland Publishing Company, Amsterdam, 1982.

[33] T. F. Mitchell. Colloquial Arabic: the Living Language of Egypt, English Universities Press, London, 1962.

[34] N. Tomiche. Le parler arabe du Caire, Mouton, Paris, 1964.

[35] M. Dziekan. Dzieje kultury arabskiej, Wydawnictwo Naukowe PWN, Warszawa, 2008, 13.

[36] Council of Europe. Europejski system opisu kształcenia językowego: uczenie się, nauczanie, ocenianie, Wydawnictwa CODN, Warszawa, 2003, 33, 109. 